\title{
Prenatal diagnosis of diastrophic dysplasia in the second trimester of pregnancy: Two- and three- dimensional ultrasonographic findings
}

\section{Gebeliğin ikinci trimesterinde diastrofik displazinin prenatal tanısı: İki ve üç boyutlu ultrasonografik bulgular}

\author{
(1) Thaísa de Souza Limal, (1) Bárbara Ghannam Ferreiral, (1) Cindy White Loureiro Souza ${ }^{2}$, (1) Isa Beatriz \\ Carminatti Batistal ${ }^{1}$, (1) Edward Araujo Júnior ${ }^{3,4}$, (1) Caetano Galvão Petrini ${ }^{1,5}$, (1) Marina Carvalho Paschoini ${ }^{1}$, \\ (1) Alberto Borges Peixoto ${ }^{1,5}$ \\ ${ }_{1}^{1}$ Department of Obstetrics and Gynecology, Federal University of Triângulo Mineiro (UFTM), Uberaba-MG, Brazil \\ 2Department of Gynecology and Obstetrics, Faculty of Medicine ABC, Santo André-SP, Brazil \\ ${ }^{3}$ Department of Obstetrics, Paulista School of Medicine - Federal University of São Paulo (EPM-UNIFESP), São Paulo-SP, Brazil \\ ${ }^{4}$ Medical course, Municipal University of São Caetano do Sul (USCS), São Paulo-SP, Brazil \\ 5Mário Palmério University Hospital, University of Uberaba (UNIUBE), Uberaba-MG, Brazil
}

\begin{abstract}
To present a prenatal diagnosis of diastrophic dysplasia in the second trimester of pregnancy using two- (2D) and three-dimensional (3D) ultrasonography. The mother was primigravida and aged 12 years. She underwent the first 2D obstetric ultrasound examination at 27 weeks, showing bilaterally upper and lower limb micromelia, thumb and hallux in bilateral abduction, bilateral talipes equinovarus; hyperlordosis of the lumbar spine, cervical, lumbar, and sacral scoliosis; cervical hyperkyphosis with the misalignment of cervical vertebrae, and straight clavicles. 3D ultrasonography in conventional and HDlive rendering modes confirmed the changes observed in 2D ultrasonography and allowed improved understanding by the parents. At birth, the newborn presented transient respiratory distress and neonatal sepsis. At the time of writing, the child is aged 31 months and under follow-up by the pediatrics department. 3D ultrasound allowed the parents to understand the fetal malformations better, and they received adequate counseling.

Keywords: Diastrophic dwarfism, osteochondrodysplasias, skeletal dysplasia, ultrasonography
\end{abstract}

Öz

Bu çalışmada, gebeliğin ikinci trimesterinde, iki (2D) ve üç boyutlu (3D) ultrasonografi kullanarak prenatal diastrofik displazi tanısı konan bir hasta sunulmuştur. Anne primigravida idi ve 12 yaşındaydı. İlk 2D obstetrik ultrason muayenesi 27. haftada yapıldı. Fetüste bilateral üst ve alt ekstremitelerde mikromeli saptandı. Her iki baş parmak abdüksiyonda idi. Bilateral talip ekinovarus, lomber hiperlordoz, servikal, lomber ve sakral skolyoz, servikal omurların yanlış hizalanması ile birlikte servikal hiperkifoz ve düz klavikulalar saptandı. Geleneksel ve HDlive oluşturma modlarında 3D ultrasonografi, 2D ultrasonografide gözlemlenen değişiklikleri doğruladı ve durumun ebeveynler tarafından daha iyi anlaşılmasını sağladı. Yenidoğanda geçici solunum sıkıntısı ve neonatal sepsis görüldü. Bu yazı yazıldığı sırada çocuk 31 aylık idi ve pediatri serviside takip ediliyordu. 3D ultrason, ebeveynlerin fetal malformasyonları daha iyi anlamalarını ve yeterli danışmanlık almalarını sağlamıştır.

Anahtar Kelimeler: Diastrofik cücelik, osteokondrodisplaziler, iskelet displazisi, ultrasonografi

\section{Introduction}

Diastrophic dysplasia (DD) is a rare skeletal malformation because of an autosomal recessive genetic alteration ${ }^{(1)}$ with an incidence of 1 case per 100,000 live births ${ }^{(2)}$. This condition was first described in 1960. It is characterized by predominantly rhizomelic micromelia, crooked feet, deformed earlobes, joint contractures, scoliosis, as well as hand changes. Usually, cognitive development has no changes ${ }^{(2,3)}$.

Address for Correspondence/Yazışma Adresi: Assoc. Prof. Edward Araujo Júnior,

Department of Obstetrics, Paulista School of Medicine - Federal University of São Paulo (EPM-UNIFESP), São Paulo-SP, Brazil

Phone: +551137965944 E-mail: araujojred@terra.com.brORCID ID: orcid.org/0000-0002-6145-2532

Received/Geliș Tarihi: 05.02.2021 Accepted/Kabul Tarihi: 21.04 .2021

${ }^{\circledR}$ Copyright 2021 by Turkish Society of Obstetrics and Gynecology

Turkish Journal of Obstetrics and Gynecology published by Galenos Publishing House 
DD is caused by a mutation in the SLC26A2 gene, which encodes the sulfate carrier anion. Therefore, the condition is called "DD of the sulfate carrier"(2). The gene mutation is located on the long arm of chromosome 5q31-q34. Mutations in this gene cause a defect in sulfate transporters of chondrocytes and fibroblasts, which interferes with endochondral ossification and consequently leads to abnormal growth and remodeling of bones and cartilage ${ }^{(4)}$.

The first prenatal diagnosis, by two-dimensional (2D) ultrasound, was performed in 1980. Usually, the condition is diagnosed during the second trimester of pregnancy, but it can be diagnosed sooner with a routine ultrasound from the $11^{\text {th }}$ to the $14^{\text {th }}$ week ${ }^{(3,5,6)}$. According to a PubMed search using the terms "DD," "diastrophic dwarfism," and "prenatal diagnosis," 13 prenatally diagnosed cases have been published in the English-language literature ${ }^{(2-14)}$. Sepulveda et al. ${ }^{(9)}$ were the first to describe a case report of prenatal diagnosis of DD using three-dimensional (3D) ultrasonography. Although a detailed 2D ultrasound evaluation can reveal shortening long bones, scoliosis, club feet and fixed, bilateral abduction of the thumbs and toes, 3D ultrasound provides clearer views of the limb anomalies, including the hitchhiker thumbs $s^{(7,9,15)}$.

DD is considered a severe but non-lethal skeletal dysplasia ${ }^{(9)}$. Death rates until early childhood reach $25 \%$, primarily because of airway obstruction and laryngotracheal stenosis ${ }^{(9,16)}$. The main differential diagnoses are campomelic dysplasia, thanatophoric dysplasia, osteogenesis imperfecta, distal arthrogryposis, Larsen syndrome, multiple pterygium syndrome, Roberts syndrome, Kniest dysplasia, mesomelic dysplasia, chondrodysplasia punctata, and achondrogenesis ${ }^{(7,11,15)}$.

This is the report of a case of prenatal diagnosis of a fetus with $\mathrm{DD}$ in which the main results of 2D and 3D ultrasonography are highlighted.

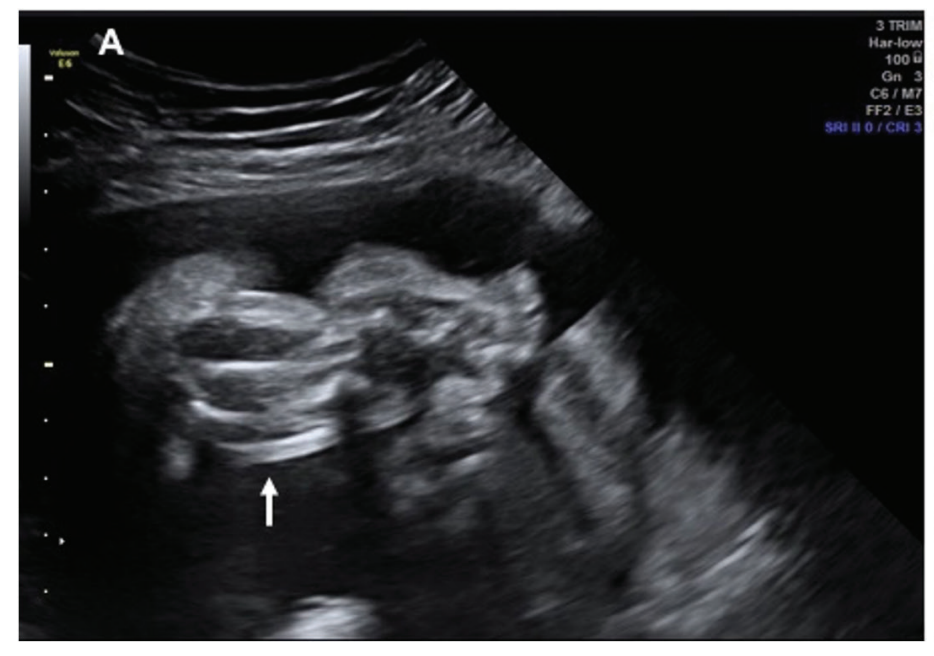

\section{Case Report}

The mother was primigravida, aged 12 years, with a late start of prenatal care, at 25 weeks of gestation. She reported no comorbidities before pregnancy and no use of psychoactive substances. During prenatal follow-up, subclinical hypothyroidism was diagnosed. There is no report of parents' consanguinity or family history of skeletal malformations.

The first 2D obstetric ultrasound examination was performed at 27 weeks, showing micromelia of all limbs (Figure 1); bilateral talipes equinovarus; hyperlordosis of the lumbar spine; cervical, lumbar, and sacral scoliosis; cervical hyperkyphosis with misalignment of cervical vertebrae; straight clavicles; normal thoracic appearance (cardiac area to thoracic area ratio: 0.31); chest circumference to waist circumference ratio: 0.77; femoral length to waist circumference ratio: 0.14; dilated cisterna magna; and an estimated fetal weight of $602 \mathrm{~g}$ (percentile 0.6). Fetal echocardiography demonstrated no evidence of abnormalities. To confirm the results observed with 2D ultrasonography, 3D ultrasonography was performed in both conventional and HDlive rendering modes, confirming the previous findings and evidencing bilateral abduction of the thumbs and halluces (Figure 2). 3D ultrasound allowed the parents to understand the fetal malformations better, facilitating counseling.

A new ultrasound series was obtained at 32 weeks and 1 day, showing a fetus with an estimated weight of $1198 \mathrm{~g}$ (percentile 0.4 ), chest circumference to waist circumference ratio of 0.67 , and femoral length to waist circumference ratio of 0.14 . The images evidenced a narrow thorax (heart area to thoracic area ratio: 0.54), hypotelorism, and straight clavicles (Figure 3). The parents refused karyotyping and fetal genetic testing even after psychological, fetal medicine, and geneticist consultant counseling. At 38 weeks of gestation, the ultrasound images demonstrated an estimated fetal weight of $1520 \mathrm{~g}$ (percentile zero); normal body and respiratory movements; normal amniotic fluid (largest vertical pocket: $4.0 \mathrm{~cm}$ ); and umbilical

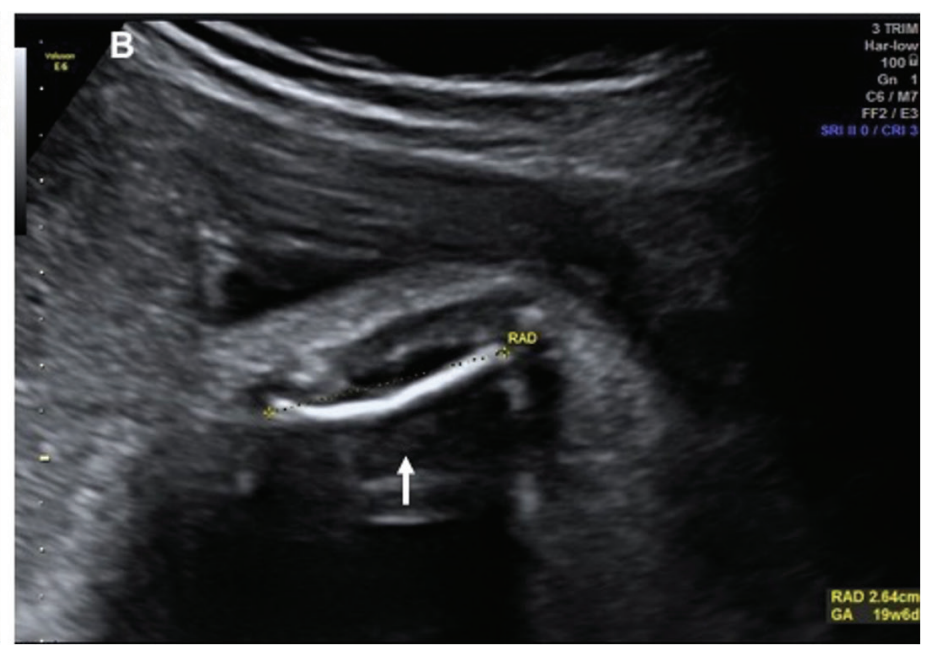

Figure 1. Two-dimensional (2D) ultrasound images of the fetus at 27 weeks of gestation showing lower and upper limbs. (A) Short lower limb (arrow). (B) Short upper limb (arrow) 

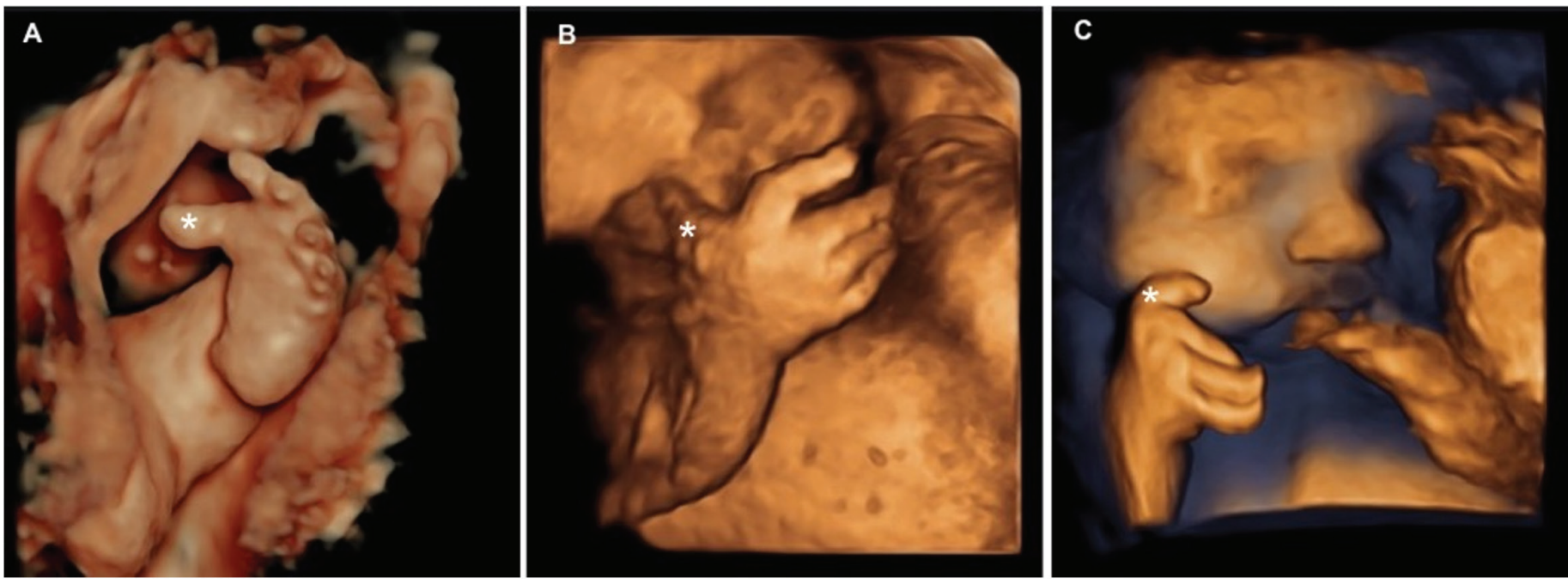

Figure 2. Three-dimensional (3D) ultrasound images of the fetus at 27 weeks of gestation, demonstrating fetal hand and foot. (A) Hallux in abduction $(*)$. (B and C) Thumbs in abduction $(*)$
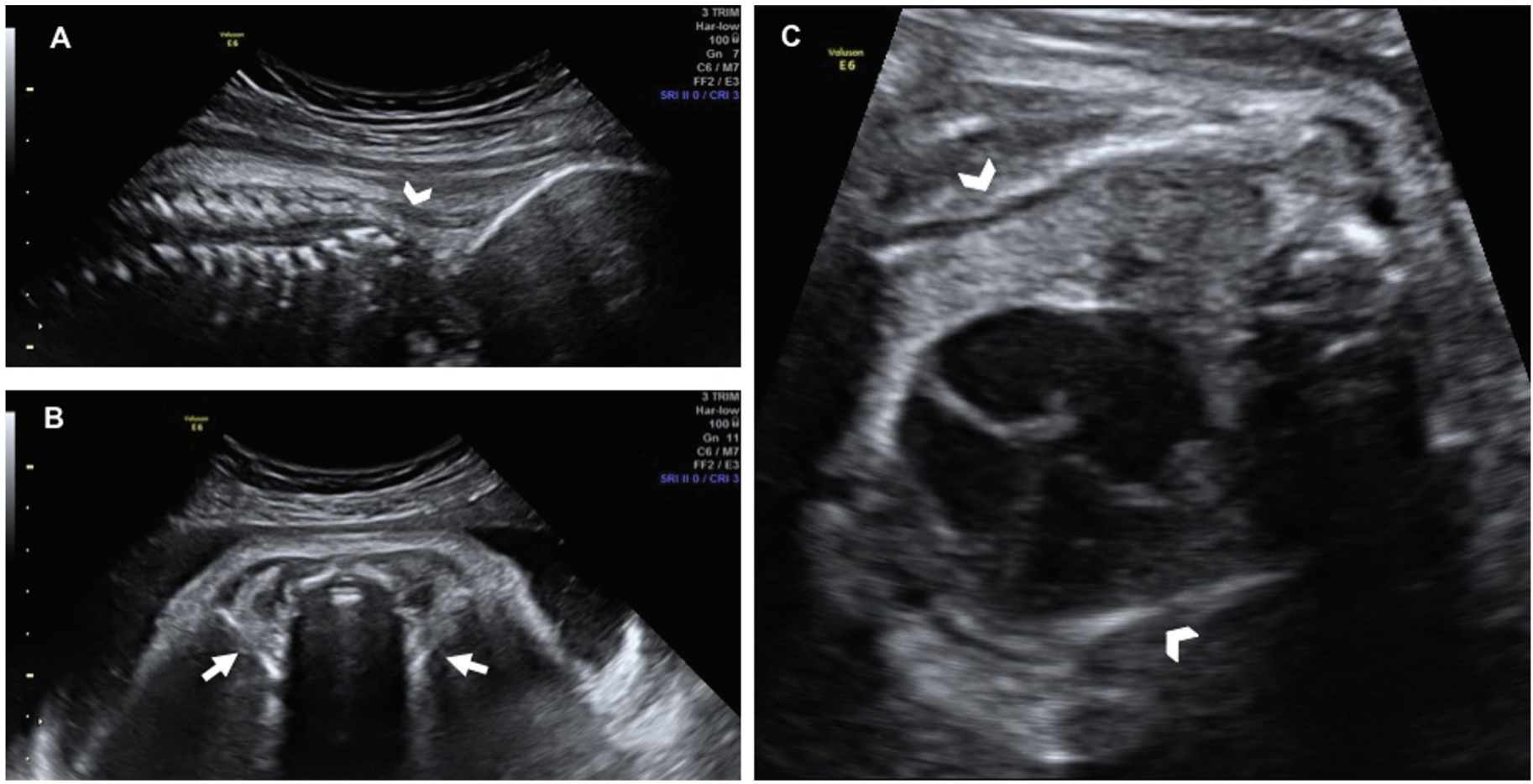

Figure 3. Two-dimensional (2D) ultrasound images of the fetus at 32 weeks of gestation showing abnormalities in fetal spine, clavicles and thorax. (A) Cervical spine misalignment (arrowhead). (B) Straight clavicles (arrow). (C) Thoracic narrowing (arrowhead)

artery Doppler with positive diastolic flow and increased pulsatility index (PI); and middle cerebral artery with PI adequate for gestational age. A cesarean section was performed due to maternal request. As the pregnant woman was an early adolescent, the parents asked for the cesarean section ether, even after medical and psychological counseling regard the benefits of vaginal delivery. The child was born alive, a boy weighing $2415 \mathrm{~g}$, height of $36 \mathrm{~cm}$, head circumference of $32 \mathrm{~cm}$, thoracic circumference of $29 \mathrm{~cm}$, abdominal circumference of $33 \mathrm{~cm}$, and an Apgar score of 8 and 9 at the first and fifth min, respectively.
The newborn evolved with a heart rate of $60 \mathrm{bpm}$ and apnea. After neonatal resuscitation maneuvers, impaired movement was observed because of limb malformations, lowering of the anterior part of the skull, auricular hematoma, long second and third fingers bilaterally, thumbs with persistent pressure, and cone-shaped thorax (Figure 4).

The newborn was referred to the neonatal intensive care unit, where he remained hospitalized for four days, evolving with improvement of the respiratory distress and without complications. Echocardiography was performed, showing a 

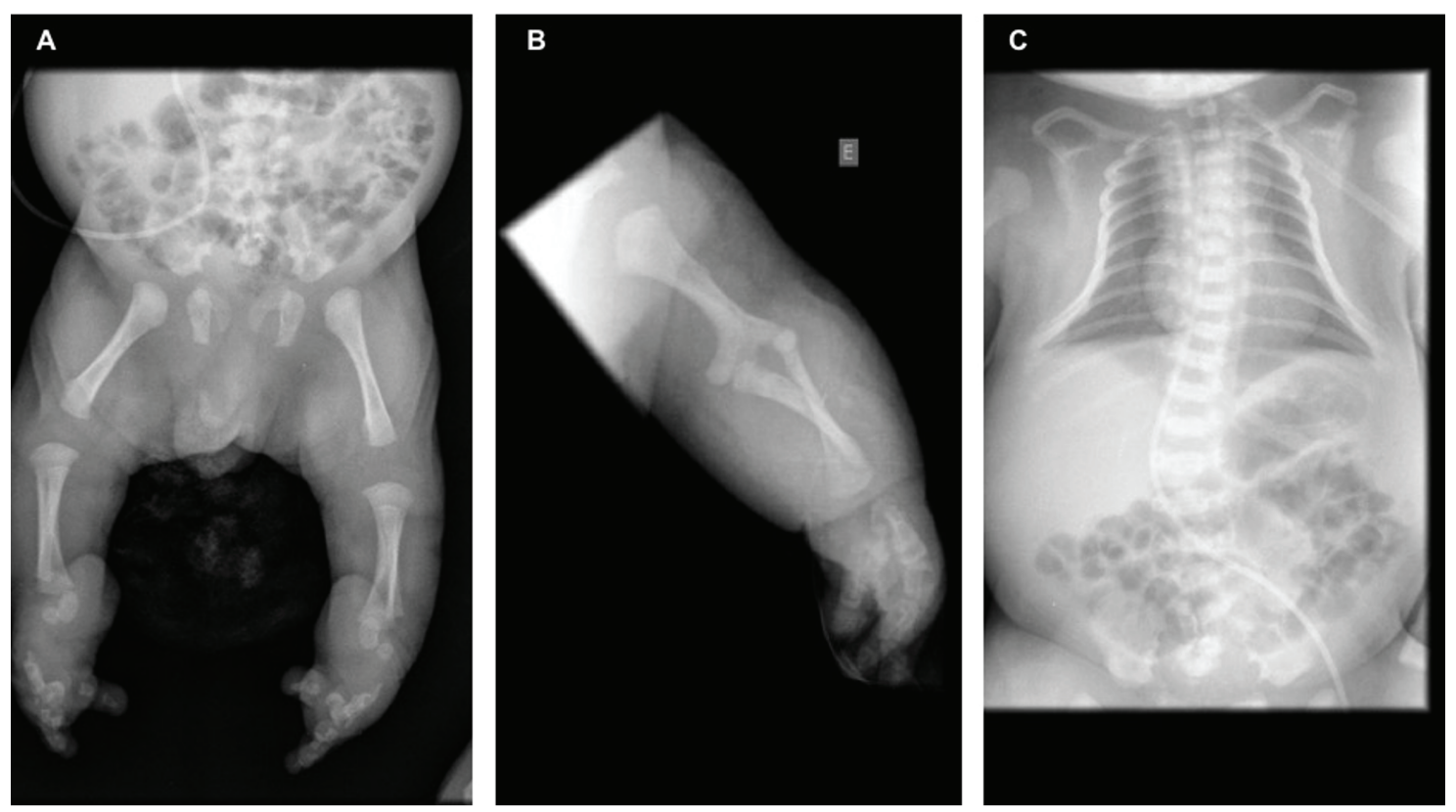

Figure 4. X-ray images of the newborn showing micromelia of lower (A) and upper (B) limbs and thoracic narrowing (C)

pervious foramen ovale. A chest X-ray showed a narrow, bellshaped thorax. An X-ray of the upper and lower limbs confirmed micromelia. A computed tomography scan of the skull showed no abnormalities. The neonatal heel-prick test showed traces of hemoglobin C. During this period, the respiratory distress improved but the newborn presented physiologic jaundice and neonatal sepsis. The septic condition was solved without complications with antibiotic therapy (ampicillin at $192.3 \mathrm{mg} /$ $\mathrm{kg} /$ dose and gentamicin at $4.3 \mathrm{mg} / \mathrm{kg} /$ day)

During the outpatient follow-up with a geneticist physician, a diagnostic hypothesis of DD and atelosteogenesis type II was formulated, based on the phenotypic picture. No cytogenetic tests were performed because of the parents' refusal. At the time of writing, the child is aged 31 months and under follow-up by the pediatrics department.

The description of this report was approved by the Research Ethics Committee of the Federal University of Triângulo Mineiro (Certificate of Presentation for Ethical Assessment: 39343420.7.0000.8667). Both the patient and her legal guardian signed an informed consent form.

\section{Discussion}

This case of DD was diagnosed in a very young adolescent, without any risk for the disease, using 2D and 3D ultrasound at the end of the second trimester of pregnancy; most ultrasound results were confirmed in the neonatal period. The interest of our report is based on three facts. First, there is only one case report on the contribution of 3D ultrasound in the diagnosis of $\mathrm{DD}^{(9)}$. Secondly, the diagnosis of $\mathrm{DD}$ was performed in a patient without risk for the disease. There are a few cases reported of the diagnosis of DD in a non-risk family ${ }^{(6,7,9,11,15,17)}$. Thirdly, this case reinforces the importance of a multidisciplinary approach manage of DD

DD is a generally severe, rare osteochondrodysplasia, first described in 1960 by Lagoy et $\mathrm{al}^{(1)}$. Its prevalence is unknown; however, it is more frequent in Finns $(3: 100,000)$, a population in which it is the most common skeletal dysplasia ${ }^{(1)}$. DD is an autosomal recessive inherited condition, encoded by a gene in the long arm of chromosome 5. Therefore, the risk of being present in another pregnancy of the same mother is $25 \%^{(1,9)}$.

DD used to be known as diastrophic dwarfism, and it was confused with achondroplasia. Studies suggest that the biochemical defect of DD is attributed to mutations in the sulfate transporter gene (SLC26A2), which impairs the functioning of the sulfate-chloride exchange in the cell membrane and leads to changes in the endochondral calcification process and consequently the abnormal formation of cartilage, interfering with the formation of the skeletal system and growth ${ }^{(2,4,6,10,11)}$.

SLC26A2 gene mutations are responsible for four clinical manifestations of chondrodysplasia: "classic" DD, multiple epiphyseal dysplasia type 4 (MED 4), atelosteogenesis type II (AO-II) and achondroplasia type 1B (ACG-1B). ACG-1B is the most severe form, often lethal either before or shortly after birth. AO-II is a form of chondrodysplasia with clinical and histopathologic manifestations similar to those found in "classic" DD; however, with additional severe phenotypes, it is associated with pulmonary hypoplasia and laryngeal stenosis with death usually during the neonatal period. MED 4 is the mildest form, characterized by joint pain, usually in the hip and knees, deformities in the hands, feet, and knees, and scoliosis ${ }^{(2,6,10)}$. In the presently reported case, evaluation with a geneticist suggested the hypotheses of DD and OO-II; however, no array comparative genomic hybridization test 
was performed for diagnostic confirmation, due to the parent's refusal to perform the tests during the prenatal and postnatal period. We believe that the very young adolescent maternal age and low social and economic level of the legal guardian for the adolescent contributed to the decision. The diagnosis of DD has already been described during the first trimester of pregnancy using 2D ultrasound ${ }^{(3,5)}$. Adolescent pregnancy and early motherhood continue to be a global public health burden ${ }^{(18)}$. The experience of multiple adversities, stress, and anxiety during pregnancy in adolescence and throughout the motherhood process could diminish the ability of the young mother to be self-efficacious ${ }^{(19)}$. In our case report, the very young adolescent maternal age may have influenced the late access of prenatal care and consequently the diagnosis of DD only at the end of the second trimester of pregnancy. During the pregnancy and puerperal period, the patient was supported by a psychology team and social workers.DD is clinically characterized by predominantly rhizomelic micromelia, i.e., long bones, crooked feet (talipes equinovarus), deformed earlobes with a cauliflower-like appearance, joint contractures, scoliosis, hand deformities, and short stature, but normal intelligence ${ }^{(3,12)}$. Deformities of the hands include brachydactyly and symphalangism of the proximal joints of the second to the fifth finger, as well as thumbs in abduction ("hitchhiker's thumb"), which are considered a pathognomonic sign of $\mathrm{DD}$, although it is not always present ${ }^{(3,12)}$. To the best of our knowledge, this is the second report on the use of 3D ultrasound in the diagnosis of DD. Sepulveda et al..$^{(9)}$ through 3D ultrasound easily demonstrated the abnormalities of long bones, hitchhiker thumbs and facial anomalies of a fetus with DD. The advantages of 3D over 2D ultrasound could be clinically important, as micrognathia and hitchhiker thumbs could easily be missed on 2D ultrasound ${ }^{(7,9,15)}$. In the present case, 3D ultrasound in rendering mode allowed a detailed evaluation of the hands and feet, including the abducted halluces and thumbs.

Other deformities that often occur in cases of DD include narrow thorax, tracheomalacia, micrognathia, and cleft palate ${ }^{(2-6)}$. In this case, the fetus had cervical and lumbar scoliosis, significant micromelia, chest narrowing, bilateral talipes equinovarus, and absence of pulmonary hypoplasia or cleft palate. After birth, rhizomelic limb shortening, bell-shaped thorax, disproportionate skull and face, auricular hematoma, bilateral abducted thumbs, and bilateral talipes equinovarus were confirmed.

The combination of clinical, radiologic, and histopathologic features allows the diagnosis of DD at birth ${ }^{(2)}$. Prenatal diagnosis is possible via 2D ultrasound; such a diagnosis was first reported in the early 1980s. Most diagnoses of DD were made in fetuses in the second trimester, as in the present report. The presence of micromelia, congenital talipes equinovarus, and finger deformities, especially thumbs in permanent abduction facilitates the recognition of this pathology. Currently, many researchers consider 3D ultrasound as the method of choice for DD diagnosis ${ }^{(2-4)}$. In this case, 3D ultrasound was useful for documenting the bilaterally abducted thumbs and halluces and the talipes equinovarus, facilitating the understanding of fetal malformations by the parents and thereby allowing better genetic counseling.

The definitive diagnosis of $\mathrm{DD}$ is made via histopathologic examination, which demonstrates the progressive destruction of cartilage, disorganization and degeneration of chondrocytes, and irregular myxoid degeneration with replacement by fibrous and even bone connective tissue. It is necessary to conduct differential diagnosis with other micromelias such as achondroplasia, congenital multiple arthrogryposis, and spondyloepiphyseal dysplasia congenita ${ }^{(3)}$.

During the neonatal period, the death rate from DD is high (25\%), usually attributed to airway obstruction. Thus, perinatal management involves strict monitoring for respiratory complications because of the risk of restrictive airway obstruction caused by tracheomalacia, progressive cervical kyphoscoliosis, and joint disease, which may be associated with congenital heart defects $^{(2,3)}$. In the present case, the only respiratory complication described was neonatal respiratory distress, which required two cycles of positive-pressure ventilation after birth. The newborn had no congenital heart disease identified either clinically or by neonatal echocardiography. During outpatient follow-up, he has shown no signs of other serious respiratory complications to date.

The treatment of DD cases comprises physiotherapy and other correlated therapies that help improve mobility ${ }^{(2)}$. Physiotherapy treatment has been offered for motor improvement and for correcting talipes equinovarus.

\section{Conclusion}

In terms of diagnosis and perinatal prognosis, the prenatal diagnosis of DD during the second trimester of pregnancy has fundamental implications. 3D ultrasound, through multiplanar evaluation, may increase the detection of the abnormalities of long bones, hands and facial abnormalities. Moreover, it allows the parents to understand fetal malformations better with adequate counseling.

\section{Ethics}

Informed Consent: Both the patient and her legal guardian signed an informed consent form.

Peer-review: Externally peer-reviewed.

\section{Authorship Contributions}

Surgical and Medical Practices: T.S.L., B.G.F., C.W.L.S., Concept: M.C.P., Design: A.B.P., Data Collection or Processing: H.Y., Analysis or Interpretation: C.G.P., Literature Search: I.B.C.B., Writing: E.A.J.

Conflict of Interest: The authors declare no conflict of interest. Financial Disclosure: The authors declared that this study received no financial support. 


\section{References}

1. Lagoy JS, Kofford ND, Gosselin BJ, Russell MA, Morley BD. Management of a parturient with diastrophic dysplasia. A A Case Rep 2015;5:6-8.

2. Honório JC, Bruns RF, Gründtner LF, Raskin S, Ferrari LP, Araujo Júnior E, et al. Diastrophic dysplasia: prenatal diagnosis and review of the literature. Sao Paulo Med J 2013;131:127-32.

3. Canto MJ, Buixeda M, Palau J, Ojeda F. Early ultrasonographic diagnosis of diastrophic dysplasia at 12 weeks of gestation in a fetus without previous family history. Prenat Diagn 2007;27:976-8.

4. Miller E, Blaser S, Miller S, Keating S, Thompson M, Unger S, et al. Fetal MR imaging of atelosteogenesis type II (AO-II). Pediatr Radiol 2008;38:1345-9.

5. Severi FM, Bocchi C, Sanseverino F, Petraglia F. Prenatal ultrasonographic diagnosis of diastrophic dysplasia at 13 weeks of gestation. J Matern Fetal Neonatal Med 2003;13:282-4.

6. Gembruch U, Niesen M, Kehrberg H, Hansmann M. Diastrophic dysplasia: a specific prenatal diagnosis by ultrasound. Prenat Diagn 1988;8:539-45.

7. Jung C, Sohn C, Sergi C. Case report: prenatal diagnosis of diastrophic dysplasia by ultrasound at 21 weeks of gestation in a mother with massive obesity. Prenat Diagn 1998;18:378-83.

8. Gollop TR, Eigier A. Prenatal ultrasound diagnosis of diastrophic dysplasia at 16 weeks. Am J Med Genet 1987;27:321-4.

9. Sepulveda W, Sepulveda-Swatson E, Sanchez J. Diastrophic dysplasia: prenatal three-dimensional ultrasound findings. Ultrasound Obstet Gynecol 2004;23:312-4.

10. Kaitila I, Ammälä P, Karjalainen O, Liukkonen S, Rapola J. Early prenatal detection of diastrophic dysplasia. Prenat Diagn 1983;3:237-44.

11. Wax JR, Carpenter M, Smith W, Grimes C, Pinette MG, Blackstone $\mathrm{J}$, et al. Second-trimester sonographic diagnosis of diastrophic dysplasia: report of 2 index cases. J Ultrasound Med 2003;22:8058.

12. Tan TY, McGillivray G, Kornman L, Fink AM, Superti-Furga A, Bonafé L, et al. Autosomal recessive omodysplasia: early prenatal diagnosis and a possible clue to the gene location. Am J Med Genet A 2005;135:324-7.

13. Maeda K, Miyamoto Y, Sawai H, Karniski LP, Nakashima E, Nishimura G, et al. A compound heterozygote harboring novel and recurrent DTDST mutations with intermediate phenotype between atelosteogenesis type II and diastrophic dysplasia. Am J Med Genet A 2006;140:1143-7.

14. Corsi A, Riminucci M, Fisher LW, Bianco P. Achondrogenesis type IB: agenesis of cartilage interterritorial matrix as the link between gene defect and pathological skeletal phenotype. Arch Pathol Lab Med 2001;125:1375-8.

15. Tongsong T, Wanapirak C, Sirichotiyakul S, Chanprapaph P. Prenatal sonographic diagnosis of diastrophic dwarfism. J Clin Ultrasound 2002;30:103-5.

16. Jones KL. Diastrophic dysplasia. In Smith's Recognizable Patterns of Human Malformation. 5th ed. Philadelphia, PA: WB Saunders; 1997:376-7.

17. Qureshi F, Jacques SM, Johnson SF, Johnson MP, Hume RF, Evans MI, et al. Histopathology of fetal diastrophic dysplasia. Am J Med Genet 1995; 56:300-3.

18. Kumar M, Huang KY. Impact of being an adolescent mother on subsequent maternal health, parenting, and child development in Kenyan low-income and high adversity informal settlement context. PLoS One 2021;16:e0248836. doi: 10.1371/journal. pone. 0248836 .

19. Bilszta JL, Tang M, Meyer D, Milgrom J, Ericksen J, Buist AE. Single motherhood versus poor partner relationship: outcomes for antenatal mental health. Aust N Z J Psychiatry 2008;42:56-65. 